IJMS 24 (1), 41-71 (2017)

\title{
INVESTMENT DECISION MAKING AMONG GULF INVESTORS: BEHAVIOURAL FINANCE PERSPECTIVE
}

\author{
BASHAR YASER ALMANSOUR \\ Finance and Economics Department, Taibah University, \\ Medina, Saudi Arabia \\ YASER AHMAD ARABYAT \\ Finance and Economics Department, Al-Balqa' Applied University, \\ Al-Salt, Jordan
}

\begin{abstract}
The rationality hypothesis has been a very popular topic among the academics. Being a widely accepted hypothesis as part of the traditional finance theories, an investor is deemed a rational agent and makes rational decisions by exhausting all available alternatives. However, recently, new behavioural finance theories have been gaining ground as many empirical findings, which have been left unanswered by the traditional theories, can be explained by these behavioural-approach based theories. This research examined the impact of psychological factors on risk-taking behaviour in investment decisions. In particular, this research considered the possible effects of psychological factors, namely herding, heuristics, prospect, market, self-attribution bias, and familiarity bias, in making investment decisions. The findings in this paper declared that risk-taking behaviour in investment is affected by herding factors, heuristics factors, prospect factors, market factors and self-attribution bias factors. The familiarity bias factors do not significantly affect risk-taking behaviour in financial investment.
\end{abstract}

Keywords: Behavioural finance, Herding, Heuristics, Prospect, Market, Self-attribution bias, Familiarity bias

Received: 26/04/2017 Revise: 16/05/2017 Accepted: 1/6/2017 Publish: 27/7/2017

\section{Introduction}

In finance theories, the individual is deemed an economic agent who is rational and always considers all available information in 
the process of making investment decisions. In addition to this, the financial market assumes stability and efficiency while the stock prices follow a random walk. For many years, due to its ability in the prediction of stock price movement, the rationality hypothesis has grown in popularity and has been widely supported by many academic researchers in the field of finance. However, in recent years, amid the increasing volatility and crashes in the market, Zoghlami and Matoussi (2009) implied that academic researchers are somewhat losing interest in this rationality hypothesis. Evidences also indicated that behavioural finance theories are potentially able to explain several empirical findings which have been left unexplained by traditional theories. Beside this, trading strategies using behavioural finance approach had been proven to be more profitable in comparison to trading strategies based on efficient financial market theory (Bloomfield 2006).

However, behavioural finance has been interpreted differently by many scholars and researchers in their own terms (Ricciardi \& Simon, 2000). Literature related to behavioural financial includes the phrases "psychology of investing" and "psychology of finance". While behavioural finance is applied by many researchers and scholars in explaining empirical findings, behavioural finance has become a household name in the financial industry (Shefrin, 2010).

Investors think of themselves as rational and logical, but when it comes to investing, their emotional inclinations, ingrained thought patterns, and psychological biases, colour how they perceive the world and how they make decisions. The controversy of this area of study is the different findings that researchers came up with (Jagongo \& Mutswenje, 2014).

Based on traditional finance theory, the price of assets is not influenced by investors' behaviour. The reason behind this depends on their demands which will be neutralised by the trades as well as the transactions of arbitrageurs, and therefore discounts the possible effects of investors' feelings (Wang, Li, \& Lin, 2009). However, according to behavioural finance theory, it claims that the prices of any asset can and will be definitely influenced by investor behaviour (De long, Shleifer, Summers, \& Waldmann, 1990; Shleifer \& Vishny, 1997).

Several researchers have put the spotlight on the field of behavioural finance which has developed rapidly in recent years, and then they 
provided evidences that investors' financial and investment decisions can be affected by internal and external behavioural factors (Shefrin, 2000; Shleifer, 2000; Warneryd, 2001; Almansour, 2015). Previous studies have suggested to conduct such studies in behaviour finance field (De long, Shleifer, Summers, \& Waldmann, 1990; Shleifer \& Vishny; 1997; Wang, Li, \& Lin, 2009; Almansour, 2015)

Investment in financial products has never been trickier and less straightforward until the financial services industry sought to increase their profitability by offering individual investors a wide assortment of sophisticated products. Though, apparently, these financial products may cater to the needs and risk appetites of the investor, making choices has also become more difficult. While there are financial institutions which are genuine in assisting investors in retirement planning and trading strategies, the lack of understanding and ignorance of investors about the complexity of these financial products are exploited by financial institutions to increase profitability at the detriment of investors. Consequently, especially in times of economic downturn or slowdown, investors bear the brunt of losses. Amid high volatility in the market, investors who are overconfident of their trading abilities and highly dependent on themselves may sustain even greater losses. Though, studies in behavioural finance are rather impressive, more often than not, these studies are based in western countries with Anglo-Saxon Culture.

Recently, the kingdom of Saudi Arabia faced another financial crisis after its underestimated gamble on oil. This led investors to be wary of investing their money in the financial markets. However, Chun and Ming (2007) documented evidence that investment decisions in the stock market are influenced to a certain extent by behavioural biases, and this supports the important role of behaviour variables in the Saudi stock market. Nonetheless, the association that the stock market of Saudi Arabia, an emerging market, is inefficient and possibly irrational, cannot be made without careful and comprehensive study on the factors that influence investment decisions made by investors in Saudi Arabia.

The theme of this research centred on identifying psychological factors that influence investors' risk-taking behaviour. Self-attribution bias which is a type of bias reinforced by overconfidence causes the investors to be overconfident about their own investment perception and opinion. Overconfidence also leads to underestimation of risks and overestimation of their own knowledge (Chuang \& Lee, 2006). 
Familiarity bias which is related to conservatism bias is another bias that has a significant role and impact in investment decision. Conservatism is a situation whereby once the individual's mind has been framed, the individual exhibits slowness or ineptitude in changing their first impression (Shefrin, 1948). The model by Barberis, Shleifer, and Vishny (1998) noted that investor conservatism bias is reflected in systematic error when making the investment decision due to their slowness in changing their beliefs. Consequently, they may react insufficiently to new information.

\section{Literature Review}

Fundamentally, the modern portfolio theory (Markowitz, 1952), market efficient hypothesis (Fama, 1970), and capital asset pricing theory (Sharpe, 1964), laid the foundations of the standard finance or traditional finance theories. In standard or traditional finance theory, the investor is depicted as an economic agent who is behaving "rationally" when buying and selling stocks. Furthermore, this theory postulated the law of one price and the market assumes efficiency as well that all the available information is fully reflected in the prices (Fama, 1970).

Until the early 1980s, the behavioural concepts that originated from the discipline of psychology by psychologists, have not been accepted and used by financial economists in behavioural decision making, even though the first research paper written on behavioural finance was formally published in the Journal of Finance in 1972 (Shefrin, 2010). Essentially, traditional finance is left unchallenged and enjoys tremendous popularity until the term "behavioural finance" was coined in the financial market in the 1980s. By the 1990s, behavioural finance gained ground as studies in this field were published in many academic journals, business publications, and even in local newspapers. Selden, in his book "Psychology of the Stock Market", was the first to apply the field of psychology in the stock market, while Shefrin and Statman (1985) were among the first to publish articles on behavioural finance discussing the influence of psychological biases on the investors' and traders' decisions in the financial market.

Meanwhile, some research articles were written on the seasonality effect and investor behaviour in the stock market. For instance, Doyle and Chen (2009) suggested that there are seasonality effects in stock markets by illustrating a set of findings as calendar "anomalies" in the 
market. "House money" effect was an effect revealed in the studies by Kim and Nofsinger (2008). In their findings, employees who are rewarded with bonuses before the Lunar New Year under Chinese tradition contribute to the "house money" effect. Accordingly, higher level of risk is more likely to be assumed by investors during the festive seasons. Investors are more optimistic about their future during Chinese New Year and as a result or underestimation of risk, they are prone to buy stock with the money they received, as suggested by Chen and Chien (2011).

Regarding behavioural finance literature, herding is depicted as the tendency of agents to imitate the behaviour of a larger group. This is known as herding attitude which is sometimes termed as herding behaviour. Impulsiveness in mental thinking in response to signals from others results in human herding behaviour. In other words, an investor may follow and imitate the action of another investor (Prechter, 2001). Benabou (2008) observed "groupthink" which is a form of collective confirmation bias for groups and a key element in herding. He noted that group members who share commonalities in certain attributes, such as background and perspectives with very little disturbance from outsider's opinion, can result in "groupthink". Bloomfield (2006) suggested that sometimes, investors find it easier to simply purchase popular stocks by just following or emulating the crowd. While the herding activities is evident in South Korea and Taiwan, there is insufficient evidence of herding in Japan as noted by Chang, Cheng, and Khorana (2000). Besides this, Zhou and Lai (2009) revealed that herding activity in Hong Kong is more popular in selling stocks over buying stocks.

Meanwhile, Michenaud, and Solnik (2008) hypothesised that regret is experienced by investors when their investments sustain lower performance in comparison to other alternative investments that would lead to a better outcome. Samuelson and Zeckhauser (1998) documented that investors learn lessons from erroneous decisions made in the past and bad experience to avoid regrettable outcomes. The idea of regret theory and the feeling of pride, as put forward by Muermann and Volkman (2007), are contributing factors that cause early realisation of gains compared to losses. In the same vein, Shefrin (2009) revealed that selling winning stocks too early or holding on to losing stocks causes regret in investors.

Then there is the familiarity bias, a bias which is associated with conservatism bias that impacts investment decisions. Once their 
mind has been framed, individuals become ineptitude or experience slowness in changing their first impression (Shefrin, 1948). The model by Barberis et al. (1998) illustrated that investors who are impacted by conservatism bias are inclined to be slow in changing their beliefs, as reflected in the systematic error of making investment decisions. In consequence, they under-react to new information. Chen, Chin, and Liu (2009) revealed that investors who suffer from conservatism bias under-react to earning announcement in Taiwan, which has an emerging market. In general, endowment or status quo bias can be applied to shed light on why investors who are impacted by familiarity bias make conservative decisions. Status quo bias is a bias experienced by investors when they tend to cling to their previous decisions even in the ever-changing environment (Samuelson \& Zeckhauser, 1988). Thus, this study investigated the possible effects of familiarity bias in decision making of investors in Saudi Arabia.

While reinforced by overconfidence, self-attribution bias causes investors to be overconfident about their own investment perception and opinion. The tendency of overreliance on their past successes and investing skills as well ignoring others are the attributes of overconfident investors (Barber \& Odean, 1999). Overconfidence bias leads to underestimation of risks and overestimation of knowledge in investors. Overconfidence in the prediction of stock prices and excessive trading can eventually lead to faulty decisions (Chuang \& Lee, 2006). In contrast, overconfidence bias was found to have no significant impact on investment decision for the Indian investors (Chandra \& Sharma, 2010). While Zoghlami and Matoussi (2009) found no evidence of overconfidence tendency effect on Tunisian investors, Lim (2012) in the Malaysian share market suggested that the investors who are gripped with pessimism tend to think that their stock prices will go down. As there are inconsistencies in past findings, the relationship between self-attribution bias and risktaking in investment was determined in this research.

In making financial decisions, male and female investors exhibit different attitudes toward risk, as postulated by Embray and Fox (1997). Evidences documented by Bajtelsmit and Bernasek (1996) suggested that while men are more willing to assume average or above average risk, women are not willing to undertake any risk. Females are described as more worried and tend to display anxiety in the process of making decisions (Ricciardi, 2008). Females are inclined to experience negative feelings about their daily life, as noted by Mattews (1991) in his findings. Female investors have the qualities of being more cautious, easier to convict, and less confident in contrast to their 
male counterparts in decision making under risk (Johnson \& Powell 1994). In their observations, Barber and Odean (1999) discovered that male investors have a higher portfolio turnover compared to their female counterparts, implying that the male investors exhibit more confidence in trading than female investors.

A study by Kiran and Rao (2005) explored the association between demographic and psychographic variables with risk-bearing capacity of Indian investors. Their questionnaire was designed and distributed to the investors. Two statistical methods were employed to analyse the collected data, namely multinomial logistic regression and factor analysis (FA), and they found that there is a strong relationship between risk-taking attitude and demographic and psychographic variables.

Meanwhile, the Saudi Stock Exchange, known as Tadawl, has been opened to qualified domestic and foreign investors. The Saudi stock exchange is the biggest and most liquid in the entire Middle East and North Africa. In terms of market capitalisation, the Saudi stock exchange records a value of US\$590 billion. From the regional perspective, as at the end of 2013, the Saudi equity market also represented over $50 \%$ of the entire GCC equity market capitalisation, and accounted for $75 \%$ of the value traded (SAMA, 2014).

In brief, the aim of this study was to determine the behaviour factors that affect investors' investment decision in the Saudi stock exchange. In other words, this study explored the impact of herding, heuristics, prospect, market, self-attribution bias, and familiarity bias on risktaking attitude in the Saudi stock exchange based on comprehensive review of previous studies; as was suggested by Heshmat (2013) that it is important to study the behaviour of investors in the kingdom of Saudi Arabia. Understanding these biases is crucial in improving the wealth of investors.

\section{Hypothesis Development and Theoretical Framework}

Based on the previous discussion, the following hypotheses were developed to investigate psychological factors that affect risk-taking in investment.

\section{Herding Factors}

According to Tan, Chiang, Mason, and Nelling (2008), they defined 
herding effect in the financial market as tendency of investor behaviour to follow the others' movements or actions. Herding plays an important role in the academic field because its factors can significantly affect stock prices and this falls under the viewpoint of asset pricing theories (Tan, Chiang, Mason, \& Nelling, 2008). Furthermore, herding can cause some emotional biases, including conformity, congruity and cognitive conflict, home bias, and gossip theories (Tan et al., 2008).

Many previous researchers studied herding factors that influence investor investment decisions (Sgroi 2003; Çelen \& Kariv 2004; Alevy, Haigh, \& List, 2007; Park \& Sgroi, 2009). A conclusion stated by Park and Sgroi (2009) was that policy makers should pay important attention and not distinguish all herding as irrational since with rational herding, improved information and clearer signals would lead to a decrease in herding, and that would significantly affect investors' investment decision. This leads to the following hypothesis which was developed to investigate the effect of herding factors in risk-taking behaviour of investors in Saudi Arabia.

$H_{1}: \quad$ There is a significant relationship between herding factors and risktaking behaviour in investment.

\section{Heuristics Factors}

According to Ritter (2003), heuristics is defined as the rules of thumb, which could make decision making in uncertain environments easier by reducing the complexity of assessing probabilities and predicting values to simpler judgments (Kahneman \& Tversky, 1974).

Generally, heuristics is quite valuable as well as useful when time is limited (Waweru et al., 2008), but sometimes they lead to biases (Kahneman \& Tversky, 1974; Ritter, 2003). Historically, Kahneman and Tversky were the first researchers who studied the factors that belong to heuristics and then the impact of heuristics on investors' investment decisions.

Furthermore, researchers have explored the factors which possibly will have effect on decision making, like heuristics (Evans, 2005; Waweru et al., 2008; Mayfield, Perdue, \& Wooten, 2008; Pasewark \& Riley, 2010). Waweru et al. (2008), and Pasewark and Riley (2010) studied the impact of behavioural factors on investment decision making and found heuristics plays a significant role in affecting 
investors when they make their decisions. Furthermore, they recommended conducting similar research into developing markets. Hence, the following hypothesis was developed to investigate the effect of heuristics factors in risk-taking behaviour of investors in Saudi Arabia.

$\mathrm{H}_{2}: \quad$ There is a significant relationship between heuristics factors and risktaking behaviour in investment.

\section{Prospect Factors}

Prospect theory was introduced by Kahneman and Tversky (1979), whereby the theory illustrates how risk and uncertainty is managed by investors. Basically, prospect theory explains the apparent regularity in human behaviour when it comes to assessing risk under uncertainty. According to Kahneman and Tversky (1979), people place much more weight on the outcomes that they perceived more certain to occur compared to the ones they consider merely probable - a characteristic known as the certainty effect. People's choices can also be influenced by the framing effect which refers to the way how people use their mental accounting ${ }^{1}$ in solving a problem. In other words, investors frequently replace rational judgment with experiences or intuition when they cannot comply with rational hypothesis in making decisions (Kahneman \& Tversky, 1979).

Meanwhile, Alpert and Raiffa (1982) contributed toward an idea which gave people poor calibration in estimating probabilities and generally overestimate their accuracy of knowledge and ability to do well. Individuals are also overconfident about good things that are going to happen in the future rather than bad things. Furthermore, individuals usually more recall their successes than failures which in turn lead to them overestimate their confidence to past positive outcomes (Alpert \& Raiffa, 1982). In general, prospect factors can be applied to shed light on why investors who are impacted by familiarity bias make conservative decisions. Hence, the following hypothesis was developed to investigate the effect of prospect factors in risk-taking behaviour of investors in Saudi Arabia.

$H_{3}: \quad$ There is a significant relationship between prospect factors and risktaking behaviour in investment.

\footnotetext{
1 Mental accounting belongs to the tendency for people in order to divide their money into separate accounts according to some criteria, such as source of money.
} 


\section{Market Factors}

According to DeBondt and Thaler (1999), investors' behaviours can significantly affect financial markets in the direction of behavioural finance. If the views of behavioural finance are accurate and correct, it is supposed that investors may possibly have over- or under-reaction to price changes or news, extrapolation of past trends into the future, lack of attention to fundamentals underlying a stock, focus on popular stocks, and seasonal price cycles. Almansour (2015) constructed a market sentiment index on the Malaysian equity market, where he constructed the index based on market variables for the period from 2000 to 2013. He found that the market variables can significantly affect stock return and therefore affect investment decisions made by investors. These market factors may significantly affect investors' investment decision making in the financial markets. Hence, the following hypothesis was developed to investigate the effect of market factors in risk-taking behaviour of investors in Saudi Arabia.

$H_{4}: \quad$ There is a significant relationship between market factors and risktaking behaviour in investment.

\section{Familiarity Bias and Risk-Taking}

Familiarity bias is associated with conservatism bias impacting investment decisions. Once their mind has been framed, individuals become inept or experience slowness in changing their first impression (Shefrin, 1948). The model by Barberis et al. (1998) illustrated that investors who are impacted by conservatism bias would be inclined to be slow in changing their beliefs, as reflected in systematic error of making an investment decision. Consequently, they under-react to new information.

Familiarity bias and risk-taking have been studied using neuroimaging by several authors (Chew \& Sagi, 2008; Hsu, Bhatt, Adolphs, Tranel, \& Camerer, 2005; Huettel, Stowe, Gordon, Warner, \& Plat, 2006). They discovered that familiarity bias can affect risk-taking in a significant way. However, over the past years, there is embryonic literature combining experimental economics and behavioural genetics to explore the genetic basis of economic decision making. In general, endowment or status quo bias can be applied to shed light on why investors who are impacted by familiarity bias make conservative 
decisions. Hence, the following hypothesis was developed to investigate the effect of familiarity bias in risk-taking behaviour of investors in Saudi Arabia.

$H_{5}: \quad$ There is a significant relationship between familiarity bias and risktaking behaviour in investment.

\section{Self-Attribution Bias and Risk-Taking}

Self-attribution bias causes investors to be overconfident about their own investment perception and opinion. The tendency of overreliance on their past successes and investing skills as well as ignoring others are the attributes of an overconfident investor (Barber \& Odean, 1999). Overconfidence bias leads to underestimation of risks and overestimation of knowledge in investors. Overconfidence in the predictions of stock prices and excessive trading can eventually lead to faulty decisions (Chuang \& Lee, 2006). Based on the discussion above, the following hypothesis was proposed to examine the relationship between self-attribution bias and risk-taking behaviour in investment.

$H_{6}: \quad$ There is a significant relationship between self-attribution bias and risk-taking behaviour in investment.

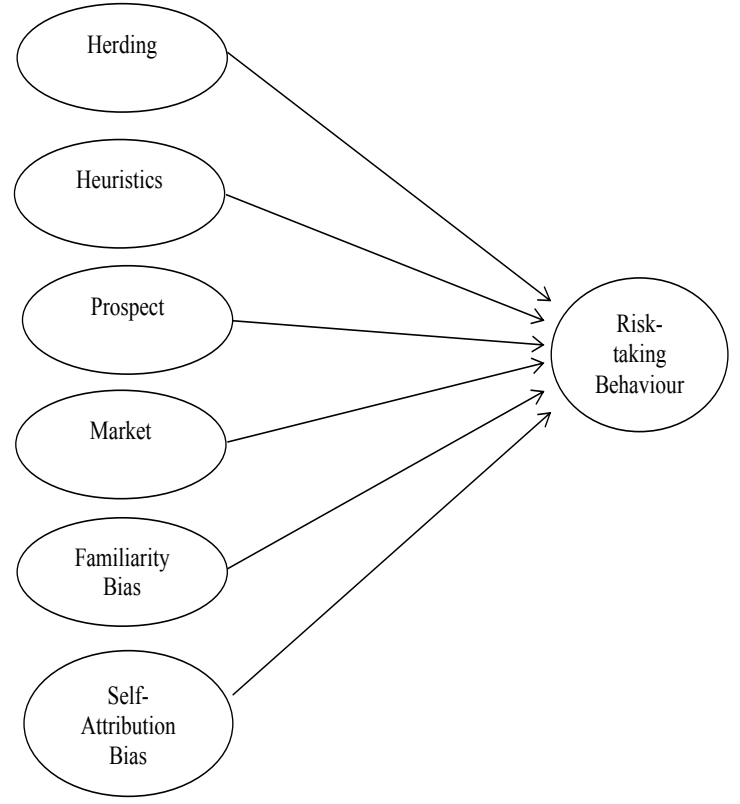


Based on the above discussion, the research framework is depicted in Figure 1. It identifies the relationships between factors of psychological biases and investors' risk-taking attitude. Two psychological factors included self-attribution bias and familiarity bias which play important roles in determining investor's risk-taking behaviour, all based on past studies done in other countries. The exogenous latent variables in this research included herding, heuristics, prospect, market, self-attribution bias, and familiarity bias. In this study, the risk-taking attitude in financial investment was the endogenous variable.

The aim of this study was to identify the psychological factors that influence investors' risk-taking behaviour in Saudi investors. Therefore, the following theoretical model was used in this study.

\section{Research Method}

Individual investors were sampled using quota sampling and snowball sampling. A Likert scale and psychometric scales were incorporated into the questionnaire. Using the Likert scale, a list of statements was prepared in this study and the respondents were asked to rate each statement on that scale, ranging from strongly agree to strongly disagree (Zikmund, Babin, Carr, \& Griffin 2010).

\section{Population}

The population of this study was all investors in the Saudi stock exchange, while the target population comprised of managers in investment banks who take orders on purchasing and selling securities. These managers were chosen because they have the key role on purchasing and selling securities in the Saudi equity market. Furthermore, this study concentrated on individual investors who frequent investment banks as well as those who go to the Saudi equity market through the Internet. In total, 175 questionnaires were distributed to the respondents, where they were given a week to complete the questionnaire. In all, a total of 170 useable questionnaires were used in the subsequent statistical analysis.

In order to investigate the effect of psychological factors that influence investors' risk-taking behaviour in Saudi investors, a qualitative approach was used. Hence, Exhibit 1 illustrates the close-ended 
questions and statements for each construct in the questionnaire.

Exhibit 1: Close-ended questions and statements for each construct in the questionnaire.

\begin{tabular}{|c|c|}
\hline Variables/Items & Author(s) \\
\hline Herding Factors & \multirow{5}{*}{$\begin{array}{l}\text { Tan, Chiang, Mason, and } \\
\text { Nelling, (2008) }\end{array}$} \\
\hline $\begin{array}{l}\text { Other investors' decisions of choosing stock } \\
\text { types have impact on your investment } \\
\text { decisions }\end{array}$ & \\
\hline $\begin{array}{l}\text { Other investors' decisions of stock volume } \\
\text { have impact on your investment decisions }\end{array}$ & \\
\hline $\begin{array}{l}\text { Other investors' decisions of buying } \\
\text { and selling stocks have impact on your } \\
\text { investment decisions }\end{array}$ & \\
\hline $\begin{array}{l}\text { You usually react quickly to changes of other } \\
\text { investors' decisions and follow their reactions } \\
\text { to the stock market }\end{array}$ & \\
\hline Heuristics Factors & \multirow{4}{*}{$\begin{array}{l}\text { Ritter (2003); Kahneman } \\
\text { and Tversky (1974) }\end{array}$} \\
\hline $\begin{array}{l}\text { You believe that your skills and knowledge of } \\
\text { stock market can help you to outperform the } \\
\text { market }\end{array}$ & \\
\hline $\begin{array}{l}\text { You rely on your previous experiences in the } \\
\text { market for your next investment }\end{array}$ & \\
\hline $\begin{array}{l}\text { You forecast changes in stock prices in the } \\
\text { future based on recent stock prices }\end{array}$ & \\
\hline Prospect Factors & \multirow{4}{*}{$\begin{array}{l}\text { Kahneman and Tversky } \\
\text { (1979); Alpert and Raiffa } \\
\text { (1982) }\end{array}$} \\
\hline $\begin{array}{l}\text { After a prior gain, you are more risk seeking } \\
\text { than usual }\end{array}$ & \\
\hline $\begin{array}{l}\text { After a prior loss, you become more risk } \\
\text { averse }\end{array}$ & \\
\hline $\begin{array}{l}\text { You avoid selling shares that have decreased } \\
\text { in value and readily sell shares that have } \\
\text { increased in value. }\end{array}$ & \\
\hline Market Factors & \multirow{3}{*}{$\begin{array}{l}\text { DeBondt and Thaler } \\
\text { (1999) }\end{array}$} \\
\hline $\begin{array}{l}\text { You have over-reaction to price changes of } \\
\text { stocks }\end{array}$ & \\
\hline $\begin{array}{l}\text { You analyse the companies' customer } \\
\text { preference before you invest in their stocks }\end{array}$ & \\
\hline
\end{tabular}


IJMS 24 (1), 41-71 (2017)

\begin{tabular}{|c|c|}
\hline Variables/ Items & Author(s) \\
\hline Familiarity Bias & \multirow{5}{*}{$\begin{array}{l}\text { Kang and Stultz } \\
\text { (1997); Frieder and } \\
\text { Subrahmanyam (2005); } \\
\text { Huberman (2001); } \\
\text { Barberis, Shleifer, and } \\
\text { Vishny (1998) }\end{array}$} \\
\hline I only invest in those familiar shares & \\
\hline $\begin{array}{l}\text { I invest mostly in well-known company with } \\
\text { recognisable products }\end{array}$ & \\
\hline $\begin{array}{l}\text { I believe the returns are higher for shares that } \\
\text { I am familiar with }\end{array}$ & \\
\hline $\begin{array}{l}\text { I would invest in the share when its company } \\
\text { announces good earnings even though I think } \\
\text { its future earnings growth is going to be } \\
\text { moderate }\end{array}$ & \\
\hline Self-Attribution Bias & \multirow{4}{*}{$\begin{array}{l}\text { Dorn \& Huberman } \\
\text { (2003); Shiller (2000); } \\
\text { Bernartzi, Kahneman, } \\
\text { and Thaler (1999) }\end{array}$} \\
\hline $\begin{array}{l}\text { My instinct has often helped me make good } \\
\text { investment }\end{array}$ & \\
\hline $\begin{array}{l}\text { I am capable of identifying the low point of } \\
\text { the market }\end{array}$ & \\
\hline $\begin{array}{l}\text { When I think about financial investment, } \\
\text { I will spend more time thinking about } \\
\text { potential gain rather than potential loss }\end{array}$ & \\
\hline \multicolumn{2}{|l|}{ Risk-Taking } \\
\hline $\begin{array}{l}\text { Consider the appropriateness of this } \\
\text { statement as a description of your own } \\
\text { personality }\end{array}$ & \multirow{4}{*}{$\begin{array}{l}\text { Garvey (2010); Jackson } \\
\text { Personality Inventory } \\
\text { and Tellegen's } \\
\text { Multidimensional } \\
\text { Personality } \\
\text { Questionnaire (MPQ) }\end{array}$} \\
\hline $\begin{array}{l}\text { I would never go hang-gliding or bungee } \\
\text { jumping }\end{array}$ & \\
\hline I would stick to the rules & \\
\hline I would avoid dangerous situations & \\
\hline
\end{tabular}

\section{Statistical Tools and Research Model}

\section{Measurement Reliability Test using Cronbach's Alpha}

The reliability and validity analysis were conducted to assess the measurement of each item and construct. Reliability was defined as an estimation of the consistency measurement. In this research, the Cronbach's alpha was considered for each scale to estimate their reliability. Table 2 demonstrates the Cronbach's alpha values for all factors employed in this study. 
IJMS 24 (1), 41-71 (2017)

Table 2

Results of Measurement Testing

\begin{tabular}{lcc}
\hline \multicolumn{1}{c}{ Variable } & Cronbach's alpha & Number of Items \\
\hline Herding Factors & 0.657 & 4 \\
Heuristics Factors & 0.661 & 3 \\
Prospect Factors & 0.691 & 3 \\
Market Factors & 0.608 & 2 \\
Familiarity Bias & 0.719 & 4 \\
Self-Attribution Bias & 0.639 & 3 \\
Risk-Taking & 0.737 & 4 \\
\hline
\end{tabular}

The results showed that Cronbach's alpha values for all scales were greater than the minimum acceptable alpha value of 0.60 . This means that the scales used in this study were internally consistent.

The aim of this paper was to identify the psychological factors that influence investors' risk-taking behaviour in Saudi investors. Therefore, the econometric model employed in this study was Ordinary Least Squared (OLS), which was aimed to examine the association between psychological factors and investors' risk. The general Ordinary Least Squared (OLS) equation is as follows:

$$
\begin{aligned}
\mathrm{RTB}_{\mathrm{i}}= & \beta_{0}+\beta_{1} \text { HERD }+\beta_{2} \text { HEUR }+\beta_{3} \text { PROS }+\beta_{4} M R K T \\
& +\beta_{5} \text { FAMI }+\beta_{6} \text { SELF }+\varepsilon_{i}
\end{aligned}
$$

where,

$\begin{array}{lll}\text { RTB } & : & \text { Risk-Taking } \\ \text { HERD } & : & \text { Herding Factors } \\ \text { HEUR } & : & \text { Heuristics Factors } \\ \text { PROS } & : & \text { Prospect Factors } \\ \text { MRKT } & : & \text { Market Factors } \\ \text { FAMI } & : & \text { Familiarity Bias } \\ \text { SELF } & : & \text { Self-Attribution Bias } \\ \text { E } & : & \text { Error } \\ \mathrm{B}_{0} & : & \text { Constant }\end{array}$


IJMS 24 (1), 41-71 (2017)

\section{Empirical Results and Hypothesis Testing}

\section{Respondent Profile}

Table 2 summarises personal information of respondents according to gender, age, education level, experience in years of trading at the stock market, and number of training sessions given to the respondents.

Table 2

Summary of Profile Respondents

\begin{tabular}{|c|c|c|c|}
\hline & Criteria & $\mathbf{n}$ & $\%$ \\
\hline \multirow{3}{*}{ Gender: } & Male & 129 & $76 \%$ \\
\hline & Female & 41 & $24 \%$ \\
\hline & Total & 170 & $100 \%$ \\
\hline \multirow{5}{*}{ Age: } & Less than 30 years & 23 & $14 \%$ \\
\hline & From $30-40$ & 78 & $46 \%$ \\
\hline & From $40-50$ & 57 & $34 \%$ \\
\hline & More than 50 years & 12 & $7 \%$ \\
\hline & Total & 170 & $100 \%$ \\
\hline \multirow{5}{*}{ Education Level: } & Secondary School & 30 & $18 \%$ \\
\hline & Bachelor Degree & 114 & $67 \%$ \\
\hline & Master Degree & 22 & $13 \%$ \\
\hline & PhD Degree & 4 & $2 \%$ \\
\hline & Total & 170 & $100 \%$ \\
\hline \multirow{4}{*}{ Experience: } & Less than 5 years & 122 & $72 \%$ \\
\hline & From 5 - less than 15 years & 47 & $28 \%$ \\
\hline & From 15 - less than 25 years & 1 & $1 \%$ \\
\hline & Total & 170 & $100 \%$ \\
\hline \multirow{4}{*}{$\begin{array}{l}\text { Number of } \\
\text { Training taken: }\end{array}$} & One training session & 19 & $11 \%$ \\
\hline & Two training sessions & 125 & $74 \%$ \\
\hline & More than two training sessions & 26 & $15 \%$ \\
\hline & Total & 170 & $100 \%$ \\
\hline
\end{tabular}

The results of descriptive statistics showed that the number of male and female investors in the sample were 129 and 41, respectively, which was a percentage value of $76 \%$ and $24 \%$. This indicated that 
male investors are paying more attention toward investing in the financial market. Most of the stock investors were aged from 30 to 40 at $46 \%$ (78 investors) of the total sample, while investors aged from 40 to 50 was recorded at $34 \%$ (57 investors) of the total sample, while $14 \%$ of the respondents were aged less than 30 years. Finally, the remaining stock investors were aged more than 50 years, which was $7 \%$ of the total sample.

The stock investors are mainly educated and have a bachelor degree. The results showed that 114 investors accounted for $67 \%$ of the total sample have a bachelor degree, while $18 \%$ of respondents have studied until secondary school, which accounted for 30 investors of the total sample. There were also stock investors who pursued their postgraduate studies and obtained a master degree and $\mathrm{PhD}$ degree, which were 22 and 4 investors (13\% and $2 \%$ of the total sample), respectively.

The results illustrated that a large proportion of the sample were investors who have experience in trading in the stock market for less than 5 years, which recorded a value of $72 \%$ of the total sample, while those investors who have experience in trading in the stock market from 5 to less than 15 years recorded a percentage value of $28 \%$, whereas, only 1 stock holder, accounting for about $1 \%$, have experience in trading in the stock market for more than 15 years.

Furthermore, the results presented that many investors have taken training programmes regarding investing in the financial market (125 investors), and they took two training programmes which accounted for $74 \%$ of the total sample. Whereas, 19 investors had taken only one training programme, which was a percentage value of $11 \%$ of the total sample, while the rest had taken more than two training programmes, which were 26 investors or $15 \%$ of the total sample.

\section{The Impact Levels of Behavioural Finance Factors on Investment Decisions}

In order to explore the impact levels of behavioural finance factors on investment decisions, the values of sample mean of each variable was obtained. Hence, the level of satisfaction was considered from the score of answers and was divided into five levels to the Likert scale, as follows: 
IJMS 24 (1), 41-71 (2017)

$$
\begin{gathered}
\text { (High score - Low score) / Number of levels } \\
\qquad \begin{array}{c}
(5-1) / 5 \\
=
\end{array} 0.80
\end{gathered}
$$

The reason that a five-point Likert scale was employed in this study was to measure the level of behavioural finance factors on investment decisions, where the value recorded by the mean of behavioural finance factors can decide their impact levels on investment decision making. In this study, the levels can be gauged by looking at Table 3 which illustrates the criteria for understanding the means of satisfaction levels.

Table 3

Criteria for Understanding Means of Satisfaction Levels

\begin{tabular}{lll}
\hline & Mean Score & Impact Level \\
\hline 1 & $1.00-1.80$ & Very low impact \\
2 & $1.81-2.60$ & Low Impact \\
3 & $2.61-3.40$ & Moderate impact \\
4 & $3.41-4.20$ & High impact \\
5 & $4.21-5.00$ & Very high impact \\
\hline
\end{tabular}

As mentioned, the impact levels of behavioural finance factors on investment decisions were presented by employing descriptive statistics. Therefore, Table 4 demonstrates the descriptive statistics for behavioural finance factors used in this study.

Table 4

Impact Levels of Behavioural Finance Factors on Investment Decisions

\begin{tabular}{lcccc}
\hline \multicolumn{1}{c}{ Variable } & $\mathbf{N}$ & Mean & $\begin{array}{c}\text { Std. } \\
\text { Deviation }\end{array}$ & $\begin{array}{c}\text { Impact } \\
\text { Level }\end{array}$ \\
\hline \multicolumn{1}{c}{ Herding Factors } & & & & High \\
\hline $\begin{array}{l}\text { Other investors' decisions } \\
\text { of choosing stock types } \\
\text { have impact on your } \\
\text { investment decisions }\end{array}$ & 170 & 3.453 & 0.80723 & impact \\
\hline & & & & (continued)
\end{tabular}


IJMS 24 (1), 41-71 (2017)

\begin{tabular}{|c|c|c|c|c|}
\hline Variable & $\mathbf{N}$ & Mean & $\begin{array}{c}\text { Std. } \\
\text { Deviation }\end{array}$ & $\begin{array}{l}\text { Impact } \\
\text { Level }\end{array}$ \\
\hline \multicolumn{5}{|l|}{ Herding Factors } \\
\hline $\begin{array}{l}\text { Other investors' decisions } \\
\text { of stock volume have } \\
\text { impact on your investment } \\
\text { decisions }\end{array}$ & 170 & 3.553 & 1.01475 & $\begin{array}{l}\text { High } \\
\text { impact }\end{array}$ \\
\hline $\begin{array}{l}\text { Other investors' decisions } \\
\text { of buying and selling } \\
\text { stocks have impact on your } \\
\text { investment decisions }\end{array}$ & 170 & 3.653 & 0.8232 & $\begin{array}{l}\text { High } \\
\text { impact }\end{array}$ \\
\hline $\begin{array}{l}\text { You usually react quickly } \\
\text { to changes of other } \\
\text { investors' decisions and } \\
\text { follow their reactions to } \\
\text { the stock market }\end{array}$ & 170 & 3.577 & 0.87539 & $\begin{array}{l}\text { High } \\
\text { impact }\end{array}$ \\
\hline \multicolumn{5}{|l|}{ Heuristics Factors } \\
\hline $\begin{array}{l}\text { You believe that your skills } \\
\text { and knowledge of stock } \\
\text { market can help you to } \\
\text { outperform the market }\end{array}$ & 170 & 3.818 & 0.81896 & $\begin{array}{l}\text { High } \\
\text { impact }\end{array}$ \\
\hline $\begin{array}{l}\text { You rely on your previous } \\
\text { experiences in the market } \\
\text { for your next investment }\end{array}$ & 170 & 4.059 & 0.76696 & $\begin{array}{l}\text { High } \\
\text { impact }\end{array}$ \\
\hline $\begin{array}{l}\text { You forecast changes in } \\
\text { stock prices in the future } \\
\text { based on recent stock } \\
\text { prices }\end{array}$ & 170 & 3.953 & 0.69497 & $\begin{array}{l}\text { High } \\
\text { impact }\end{array}$ \\
\hline \multicolumn{5}{|l|}{ Prospect Factors } \\
\hline $\begin{array}{l}\text { After a prior gain, you are } \\
\text { more risk seeking than } \\
\text { usual }\end{array}$ & 170 & 3.553 & 0.92954 & $\begin{array}{l}\text { High } \\
\text { impact }\end{array}$ \\
\hline $\begin{array}{l}\text { After a prior loss, you } \\
\text { become more risk averse }\end{array}$ & 170 & 3.647 & 0.79504 & $\begin{array}{l}\text { High } \\
\text { impact }\end{array}$ \\
\hline $\begin{array}{l}\text { You avoid selling shares } \\
\text { that have decreased in } \\
\text { value and readily sell } \\
\text { shares that have increased } \\
\text { in value }\end{array}$ & 170 & 3.271 & 0.98375 & $\begin{array}{l}\text { Moderate } \\
\text { impact }\end{array}$ \\
\hline \multicolumn{5}{|l|}{ Market Factors } \\
\hline $\begin{array}{l}\text { You have over-reaction to } \\
\text { price changes of stocks }\end{array}$ & 170 & 3.288 & 0.75712 & $\begin{array}{l}\text { Moderate } \\
\text { impact }\end{array}$ \\
\hline
\end{tabular}




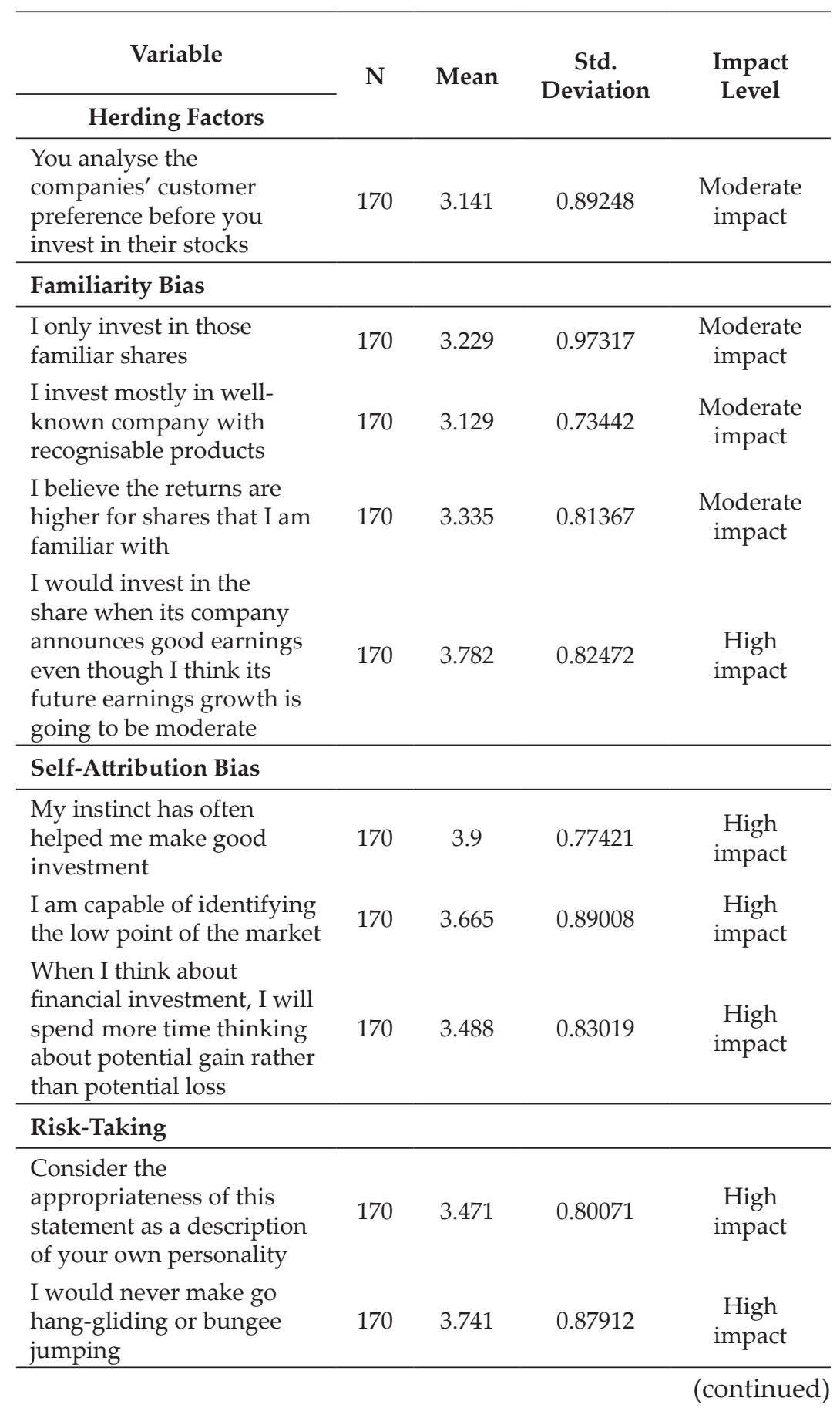




\begin{tabular}{ccccc}
\hline \multicolumn{1}{c}{ Variable } & N & Mean & $\begin{array}{c}\text { Std. } \\
\text { Deviation }\end{array}$ & $\begin{array}{c}\text { Impact } \\
\text { Level }\end{array}$ \\
\hline Herding Factors & 170 & 3.759 & 0.79611 & $\begin{array}{c}\text { High } \\
\text { impact } \\
\text { I would stick to the rules }\end{array}$ \\
$\begin{array}{l}\text { I would avoid dangerous } \\
\text { situations }\end{array}$ & 170 & 3.782 & 0.84597 & impact \\
\hline
\end{tabular}

Table 4 illustrates the impact levels of behavioural finance factors on investment decisions. For herding factors, the results showed that the maximum value recorded in herding items was 3.653 with a standard deviation of 0.8232 ("Other investors' decisions of buying and selling stocks have impact on your investment decisions"). The minimum value recorded in herding items was 3.453 with a standard deviation of 0.80723 ("Other investors' decisions of choosing stock types have impact on your investment decisions"). As a conclusion, the herding factors have a high-level impact on investment decisions; this means that the individual investors are likely to consider carefully the information of other investors' decision before making their investment decisions in the stock market.

Meanwhile for heuristics factors, the results showed that the maximum value recorded in heuristics items was 4.059 with a standard deviation of 0.76696 ("You rely on your previous experiences in the market for your next investment"). The minimum value recorded in heuristics items was 3.818 with a standard deviation of 0.81896 ("You believe that your skills and knowledge of stock market can help you to outperform the market"). As a conclusion, the heuristics factors have a high-level impact on investment decisions. This means that the investors at the stock market would be likely to lean on the recognisable and accessible information for their shares investment. In other words, the investors tend to rely on the information given by their friends, relatives, or local investors' sources rather than international sources.

Next, for prospect factors, the results showed that the maximum value recorded in prospect items was 3.647 with a standard deviation of 0.79504 ("After a prior loss, you become more risk averse"). The minimum value recorded in prospect items was 3.271 with a standard deviation of 0.98375 ("You avoid selling shares that have decreased in value and readily sell shares that have increased in value"). As a conclusion, the prospect factors have a high-level impact on 
investment decisions; this means that the individual investors are likely to consider carefully their decisions after a prior loss and therefore they would become risk averse toward their investment in the stock market. Conversely, the investors would become risk seeking after a prior gain. As a general rule, the mechanisms of investment portfolio have common associations to each other, and together impact the investors' trading decisions, so that the investors' investment performance will be affected negatively.

In the meantime, for market factors, the results showed that the maximum value recorded in market items was 3.288 with a standard deviation of 0.75712 ("You have over-reaction to price changes of stocks"). The minimum value recorded in market items was 3.141 with a standard deviation of 0.89248 ("You analyse the companies' customer preference before you invest in their stocks"). As a conclusion, the market factors have a moderate level impact on investment decisions; this means that the individual investors tend to consider general information of the past stock prices as well the current stock prices carefully before they make their investment decisions in the stock market.

Meanwhile for familiarity bias factors, the results showed that the maximum value recorded in familiarity bias items was 3.782 with a standard deviation of 0.82472 ("I would invest in the share when its company announces good earnings even though I think its future earnings growth is going to be moderate"). The minimum value recorded in familiarity bias items was 3.129 with a standard deviation of 0.73442 ("I invest mostly in well-known company with recognisable products"). As a conclusion, the familiarity bias factors have a moderate level impact on investment decisions; this means that the individual investors are not likely to consider shares unknown to them in their investment decisions in the stock market. In other words, the investors were most likely to invest in stocks that they are familiar with.

For self-attribution bias factors, the results show that the maximum value recorded in self-attribution bias items was 3.9 with a standard deviation of 0.77421 ("My instinct has often helped me make good investment"). The minimum value recorded in self-attribution bias items was 3.488 with a standard deviation of 0.83019 ("When I think about financial investment, I will spend more time thinking about potential gain rather than potential loss"). As a conclusion, the self-attribution bias factors have a high-level impact on investment 
decisions; this means that the individual investors are likely to consider carefully their behaviour as well as spending more time thinking before making their investment decisions in the stock market.

Finally, for risk-taking factors, the results show that the maximum value recorded in risk-taking items was 3.782 with a standard deviation of 0.84597 ("I would avoid dangerous situations"). The minimum value recorded in risk-taking items was 3.471 with a standard deviation of 0.80071 ("Consider the appropriateness of this statement as a description of your own personality"). As a conclusion, the risk-taking factors have a high-level impact. This means that the consequences of investment do not convince moderately the individual investors' forecasting.

\section{Influences of Behavioural Factors on Risk-Taking}

In order to investigate the influences of behavioural factors on risktaking, regression analysis was employed. With the intention of employing multiple linear regression analysis, the data were tested for and had met several assumptions, namely data size, outliers, normality, linearity, heteroscedasticity, and multicollinearity (Hair, Anderson, Tatham, \& Black, 1995; Almansour, 2015). Table 5 shows the influences of herding, heuristics, prospect, market, self-attribution bias, and familiarity bias on risk-taking.

Table 5

Influences of Behavioural Factors on Risk-Taking

\begin{tabular}{lcccccc}
\hline & \multicolumn{2}{c}{$\begin{array}{c}\text { Unstandardised } \\
\text { Coefficients }\end{array}$} & $\begin{array}{c}\text { Standardised } \\
\text { Coefficients }\end{array}$ & & \\
\cline { 2 - 5 } \multicolumn{1}{c}{ Model } & $\mathrm{B}$ & Std. Error & Beta & $\mathrm{t}$ & Sig. \\
\hline (Constant) & .734 & .242 & & & 3.030 & .003 \\
Herding Factors & -.206 & .095 & -.255 & -2.177 & .031 \\
Heuristics Factors & .595 & .117 & .657 & 5.073 & .000 \\
Prospect Factors & -.394 & .128 & -.335 & -3.084 & .002 \\
Market Factors & -.445 & .121 & -.356 & -3.675 & .000 \\
Familiarity Bias & .019 & .120 & .014 & & .158 & .875 \\
Self-Attribution Bias & 1.200 & .082 & .981 & & 14.707 & .000 \\
\hline
\end{tabular}




\begin{tabular}{llllll}
\hline & \multicolumn{2}{c}{$\begin{array}{c}\text { Unstandardised } \\
\text { Coefficients }\end{array}$} & $\begin{array}{c}\text { Standardised } \\
\text { Coefficients }\end{array}$ & & \\
\cline { 2 - 3 } \multicolumn{1}{c}{ Model } & B & Std. Error & Beta & & Sig. \\
\hline F- Statistic & 83.286 & & & & \\
$\mathrm{R}^{2}$ & $75.4 \%$ & & & \\
Adjusted R & & & & \\
Durbin-Watson & $74.5 \%$ & & & \\
Collinearity & 1.858 & & & \\
Heteroscedasticity & No & & & \\
Normality & Data is normally distributed & & \\
\hline
\end{tabular}

* Sig at level 5\%

** Sig at level $10 \%$

The results in the table above show the influences of behavioural factors on risk-taking. From the results, it can be observed that the overall model is inadequate due to a high F-statistic (83.286) and a good percentage of $\mathrm{R}^{2}$ which recorded a value of $75.4 \%$. This implies that on average the variability in the behavioural factors can explain $75.4 \%$ of the variability in the risk-taking. The Durbin-Watson value was 1.858 , which is located between the acceptable values of 1.5 and 2.5 (Hair, Anderson, Tatham, \& Black, 1995; Almansour, 2015).

Furthermore, the results showed that herding factors have a significant negative coefficient of -0.206 with a probability value of 0.031 . This means that there is a significant and negative relationship between herding factors and risk-taking behaviour in investment; this result is consistent with previous studies (Sgroi 2003; Çelen \& Kariv 2004; Alevy et al., 2007; Park \& Sgroi, 2009). Moreover, the heuristics factors have a significant positive coefficient of 0.595 with a probability value of 0.000 . This means that there is a significant and positive relationship between heuristics factors and risk-taking behaviour in investment; this result is consistent with previous studies (Evans, 2005; Waweru et al., 2008; Mayfield et al., 2008; Pasewark \& Riley, 2010).

Additionally, the results indicated that the prospect factors have a significant negative coefficient of -0.394 with a probability value of 0.002 . This means that there is a significant and negative relationship between prospect factors and risk-taking behaviour in investment; this result is consistent with previous studies (Alpert \& Raiffa, 1982; Lehenkari \& Perttunen, 2004; Shefrin \& Statman, 1985). In addition, 
the results indicated that the market factors have a significant negative coefficient of -0.445 with a probability value of 0.000 . This means that there is a significant and negative relationship between market factors and risk-taking behaviour in investment; this result is also consistent with previous studies (DeBondt \& Thaler, 1999; Almansour, 2015).

Moreover, the results confirmed that familiarity bias factors do not have a significant impact on risk-taking behaviour in investment which has positive coefficient of 0.019 with a probability value of 0.875 . This means that there are no significant relationships between prospect factors and risk-taking behaviour in investment. Finally, a significant relationship between self-attribution bias factors and risktaking behaviour in investment was found, which recorded a positive coefficient value of 1.200 with a probability value of 0.000 . This result is consistent with previous studies (Barber \& Odean, 1999; Chuang \& Lee, 2006).

In summary, the hypotheses that have been previously proposed had been tested. The results of these hypotheses are presented in Table 6 .

Table 6

Summary of Testing Hypothesis

\begin{tabular}{lll}
\hline $\mathbf{N}$ & Hypothesis & Results \\
\hline $\mathbf{H}_{1}$ & $\begin{array}{l}\text { There is a significant relationship between herding } \\
\text { factors and risk-taking behaviour in investment }\end{array}$ & Accepted \\
$\mathbf{H}_{2}$ & $\begin{array}{l}\text { There is a significant relationship between heuristics } \\
\text { factors and risk-taking behaviour in investment }\end{array}$ & Accepted \\
$\mathbf{H}_{3}$ & $\begin{array}{l}\text { There is a significant relationship between prospect } \\
\text { factors and risk-taking behaviour in investment }\end{array}$ & Accepted \\
$\mathbf{H}_{4}$ & $\begin{array}{l}\text { There is a significant relationship between market } \\
\text { factors and risk-taking behaviour in investment }\end{array}$ & Accepted \\
$\mathbf{H}_{5}$ & $\begin{array}{l}\text { There is a significant relationship between familiarity } \\
\text { bias and risk-taking behaviour in investment }\end{array}$ & Rejected \\
$\mathbf{H}_{6}$ & $\begin{array}{l}\text { There is a significant relationship between self- } \\
\text { attribution bias and risk-taking behaviour in } \\
\text { investment }\end{array}$ & Accepted \\
\hline
\end{tabular}




\section{Discussion and Conclusion}

The main objective of this paper was to present the investigation into the impact of behavioural finance factors on risk-taking behaviour in investment. Behavioural finance factors that were examined in this study were herding factors, heuristics factors, prospect factors, market factors, self-attribution bias factors, and familiarity bias factors. The results concluded that risk-taking behaviour in investment is affected by herding factors, heuristics factors, prospect factors, market factors, and self-attribution bias factors. The familiarity bias factors do not significantly affect risk-taking behaviour in investment.

Most of these behavioural finance factor items have a high-level impact on risk-taking behaviour in investment. There are a small number of items having moderate level of impact, including: "You avoid selling shares that have decreased in value and readily sell shares that have increased in value", "You have over-reaction to price changes of stocks", "You analyse the companies' customer preference before you invest in their stocks", "I only invest in those familiar shares", "I invest mostly in well-known company with recognisable products", and "I believe the returns are higher for shares that I am familiar with".

Further researchers may focus on conducting research on institutional investors in the Saudi equity market. Moreover, this paper recommends that a test needs to be performed on the behavioural finance theory effect on the efficiency of the stock market. In addition, interested parties may employ the impact of behavioural finance factors on investment decisions by looking at different stock markets to compare.

\section{References}

Alevy, J., Haigh, M., \& List, J. (2007). Information cascades: Evidence from an Experiment with Financial Market Professionals, Journal of Finance, 62(1), 151-80.

Almansour, B. (2015). The Impact of Market Sentiment Index on Stock Returns: An Empirical Investigation on Kuala Lumpur Stock Exchange. Journal of Arts, Science \& Commerce, VI, (3).

Bajtelsmit, V. L., \& Bernasek, A. (1996). Why do women invest differently than men? Financial Counselling and Planning, 7, pp. $1-10$. 
Barber, B. M., \& Odean, T. (1999). Boy will be boys: Gender overconfidence and common stock investment. Working paper, University of California

Barber, B., \& Odean, T. (1999). Online investor: Do the slow die first. Working Paper.

Barberis, N., Shleifer, A., \& Vishny, R. (1998). A model of investor sentiment. Journal of Financial Economics, 49, 307-343.

Bartlett, M. S. (1954). A note on the multiplying factors for various chi square approximations. Journal of the Royal Statistical Society, 16, 296-298.

Benabou, R. (2008). Groupthink: Collective delusion in organization and markets. Working Paper.

Bernartzi, S., Kahneman, D., \& Thaler, R. (1999). Optimism and overconfidence in asset allocation decision. Retrieved from http:// news.morningstar.com.

Bloomfield, R. J. (2006a). Behavioural finance. The Social Science Research Network Electronic Paper Collection, 1-16.

Bloomfield, R. J. (2006b). Behavioural finance. Johnson School Research Paper Series.

Celen, B., \& Kariv, S. (2004), Distinguishing Informational Cascades from Herd Behaviour in the Laboratory, American Economic Review, 94(3), 484-498.

Cohen, J. (1988). Statistical power analysis for the behavioural sciences (2nd ed.). Hillsdale, NJ: Lawrence Erlbaum Associates.

Chandra, A., \& Sharma, D. (2012). Investment management by individual investor: Behavioural approach. The IUP Journal Behavioural Finance, 7(1\&2).

Chang, E. C., Cheng, J. W., \& Khorana, A. (2000). An examination of herd behaviour in equity market: An international perspective. Journal of Banking and Finance, 24, 1651-1679.

Chen, H. W., Chin, S. W., \& Liu, V. W. (2009). The conservatism bias in an emerging stock market: Evidence from Taiwan. Pacific-Basin Finance Journal, 17, 494-505.

Chen, T. C., \& Chien, C. C. (2011). Size effect in January and cultural influences in an emerging stock market: The perspective of behavioural finance. Pacific-Basin Finance Journal, 19(2), 208-229.

Chew S. H., \& Sagi, S. J. (2006). Event Exchangeability: Probabilistic Sophistication without Monotonicity or Continuity, Econometrica, 74, 771-786.

Chuang, W. I., \& Lee, B. S. (2006). An empirical evaluation of the overconfidence hypothesis. Journal of Banking and Finance, 30, 2489-2515.

Cohen, J. (1988). Statistical Power Analysis for the behavioural sciences $\left(2^{\text {nd }}\right.$ ed.). Hillsdale, NJ: Lawrence Earlbaum Associates. 
Department of Statistics (2010). Population and housing census of Malaysia. Malaysia.

Doyle, J. R., \& Chen, C. H. (2009). The wandering weekday effect in major stock markets. Journal of Banking and Finance, 33, 13881399.

Embray, L. L., \& Fox. J. J. (1997). Gender differences in the investment decision-making process. Association for Financial Counselling and Planning Education, 33-40.

Evans, D. A. (2006). Subject perceptions of confidence and predictive validity in financial cues. Journal of behavioural Finance, 7(1),1228.

Fama, E. (1970). Efficient capital markets: A review of theory and empirical. Journal of Finance, 25, 383-417.

Fornell, C., \& Larcker, D. F. (1981). Evaluating structural equation models with unobservable variables and measurement error. Journal of Marketing Research, 18(1), 39-50.

Frieder, L., \& Subrahmanyam, A. (2005). Brand Perception and the market for common stock. Journal of Financial and Quantitative Analysis, 40(1), 57-86.

Garvey, J. (2010). An investigation into risk propensity in bull and bear markets. Journal of Risk Research, 13(6),789-804.

Grinblatt, M., \& Keloharj, M. (2000). The investment behaviour and performance of various investor types: A study of Finland's unique data set. Journal of Financial Economics, 55, 43-67.

Hair, J. F., Black, W. C., Babin, B. J., \& Anderson, R. E. (2009). Multivariate Data Analysis ( $7^{\text {th }}$ ed.). Upper Saddle River, NJ: Prentice Hall.

Hsu, M., Bhatt, M., Adolphs, R., Tranel, D., \& Camerer, C. F. (2005). Neural systems responding to degrees of uncertainty in human decision making. Science, 310, 1680-1683.

Huberman, G. (2001). Familiarity breeds investment. Review of Financial Studies, 14(3), 659-780.

Huettel, S. A., Stowe, C. J., Gordon, E. M., Warner, B. T., \& Plat, M. L. (2006). Neural signatures of economic preferences for risk and ambiguity. Neuron, 49, 765-775.

Johnson, J., \& Powell, P. (1994). Decision making, risk and gender: Are Manager different. British Journal of Management, 123-138.

Kahneman, D., Knetsch, J. L., \& Thaler, R. H. (1991). Anomalies: The endowment effect, loss aversion, and status quo bias. The Journal of Economic Perspectives, 5(1), 193-206.

Kaiser, H. (1970). A second generation Little Jiffy. Psychometrika, 39, 401-415.

Kaiser, H. (1974). An index of factorial simplicity. Psychometrika, 39, 31-36. 
Kang, J. K., \& Stultz, R. M. (1997). Why is there home bias? An analysis of foreign portfolio equity ownership in Japan. Journal of Financial Economics, 46, 3-28.

Lakonishok, J., Shleifer, A., Thaler, R. H., \& Vishny. R. W. (1992). The structure and performance of money management industry. Brookings Papers on Economic Activity. Microeconomics, 339391.

Lehenkari, M., \& Perttunen, J. (2004). Holding onto the losers: Finish evidence. The Journal of Behavioural Finance, 5(2), 116-126.

Lim, A. L. C. (2012). Psychological Biases and Investor Behaviour: Survey Evidence from Malaysian Stock Market. International Journal of Social Science, Economics and Arts, 2, 74-80.

Lutje, T., \& Menkhoff, L. (2003). Risk Management, Rational Herding and Institutional investor: A macroview. Discussion paper, 285.

Lutje, T. (2009). To be good or to be better: asset manager's attitudes towards herding. Applied Financial Economics, 19, 825-839.

Mattews, A. M. (1991). If I Think About the Money So Much, Why Can't I Figure It Out: Understanding and Overcoming Your Money Complex. New York: Sumbit book.

Mayfield, C., Perdue, G., \& Wooten, K. (2008). Investment management and personality type. Financial Services Review, 17, 219-236.

Michenaud, S. B., \& Solnik, B. (2008). Applying regret theory to investment choice: currency hedging decisions. Journal of International Money and Finance, 677-694.

Muermann, A., \& Volkman, J. M. (2007). Regret, pride, and the disposition effect. Working Paper.

Nofsinger, J. R., \& Sias, R. (1999). Herding and Feedback trading by institutional and individual. Journal of Finance, 54, 2283-2295.

Nofsinger, J. R. (2001). The psychology of investing ( $2^{\text {nd }}$ ed.). Upper Saddle River: Pearson Prentice Hall.

Nunnally, J. C., (1978). Psychometric Theory. New York: McGraw-Hill.

Olsen, R. A., \& Cox, C. M. (2001). The influence of Gender on the perception and response to Investment risk: The case of professional investors. The Journal of Psychology and Financial Markets, 2, 29-36.

Park, A., \& Sgroi, D. (2009). Herding and Contrarian Behaviour in Financial Markets: An Experimental Analysis, Cambridge Working Papers in Economics, CWPE No. 0938, Faculty of Economics, University of Cambridge.

Pasewark, W. R., \& Riley, M. E. (2010). It's a matter of principal: The role of personal values in investment decision. Journal of Business Ethics, 93, 237-253. 
Prechter, R. R. (2001). Unconscious Herding Behaviour as the psychological basis of financial market trends and patterns. The Journal of Psychology and Financial Markets, 2(3), 120-125.

Ralph Estes, J. H. (2001). The gender gap on Wall Street: An Empirical Analysis of Confidence in Investment decision making. The Journal of Psychology, 122(6), 577.590.

Ricciardi, V., \& Simon, H. K. (2000). What is behavioural finance. Business, Education and Technology Journal, 1-9.

Ricciardi, V. (2008). The Financial Psychology of Worry and Women. Working Paper, 1-53.

Samuelson, W., \& Zeckhauser, R. (1988). Status quo Bias in decision making. Journal of Risk and Uncertainty, 1, 7-59.

Sharpe, W. (1964). Capital assets prices: A theory of market equilibrium under conditions of risk. Journal of Finance, 19, 425-442.

Shefrin, H. (1948). Behavioural Corporate Finance Decision that create value. Santa Clara University: McGraw-Hill Irwin.

Shefrin, H. (1948). Beyond Greed and Fear: Understanding Behavioural Finance and the Psychology of Investing. Boston, Massachusetts: Harvard Business School Press.

Shefrin, H. (2009). Behaviouralising finance. Foundation and Trend in Finance, 1-184.

Shefrin, H., \& Statman, M. (1985). The disposition to sell winners too early and ride losers too long: Theory and evidence. Journal of Finance, 40(3), 777-790.

Sgroi, D. (2003). The Right Choice at the Tight Time: A Herding Experiment in Endogenous Time, Experimental Economics, 6(2), 159-80.

Shiller, R. J. (1989). Market volatility. Cambridge: MIT Press.

Shiller, R. J. (2000). Irrational Exuberance. Princeton University Press.

Simon, R. W., \& Nath, L. E. (2004). Gender and Emotion in the United States: Do Men and Women Differ in Self-reports of feeling and expressive Behaviour? American Journal of Sociology, 109(5), 1137-1176.

Strong, N., \& Xu, X. (2003). Understanding equity home bias: Evidence from survey data. Review of Economics and Statistics, 85(2), 307312.

Svenson, O. (1981). Are We All Less Risky and More Skilful than our Fellow Drivers? Acta Psychologica, 47, 143-148.

Thaler, R. H. (1980). Toward a positive theory of consumer choice. Journal of Economic Behaviour and Organisation, (1), 39-60.

Tversky, A., \& Kahneman, D. (1981). The framing of decisions and the psychology of choice. Science, 211, 453-458. 
Tversky, A., \& Kahneman, D. (1992). Advances in Prospect Theory: Cumulative Representation of Uncertainty. Journal of Risk and Uncertainty, 5, 297-323.

Waweru, N. M., Munyoki, E., \& Uliana, E. (2008). The effects of behavioural factors in investment decision making: A survey of institutional investors operating at the Nairobi Stock Exchange. International Journal of Business and Emerging Markets, 1(1), 2441.

Zhou, R. T., \& Lai, R. N. (2009). Herding and information based trading. Journal of Empirical Finance, 16, 388-393.

Zikmund, W. G., Babin, J., Carr, J. C., \& Griffin, M. (2010). Business Research Methods (8th ed.). USA: South Western Cengage Learning.

Zoghlami, F., \& Matoussi, H. (2009). A Survey of the Tunisian Investors' Behaviours. International Research Journal of Finance and Economics, 66-82. 